\title{
Alternaric acid stimulates phosphorylation of His-tagged RiCDPK2, a calcium-dependent protein kinase in potato plants
}

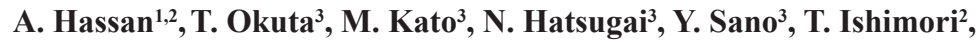 \\ K. Okazaki' ${ }^{2}$ M.A. Doullah' ${ }^{2}$ and M.M. Shah ${ }^{1}$ \\ 'Biotechnology Program, Department of Environmental Sciences, \\ COMSATS Institute of Information Technology, Abbottabad, Pakistan \\ ${ }^{2}$ Graduate School of Science and Technology, Niigata University, \\ Niigata, Japan \\ ${ }^{3}$ Faculty of Agriculture, Niigata University, Niigata, Japan \\ Corresponding author: M.M. Shah \\ E-mail: mmshah@ciit.net.pk
}

Genet. Mol. Res. 11 (3): 2381-2389 (2012)

Received August 25, 2011

Accepted January 16, 2012

Published May 10, 2012

DOI http://dx.doi.org/10.4238/2012.May.10.1

\begin{abstract}
Calcium-dependent protein kinases (CDPK) are an essential component of plant defense mechanisms against pathogens. We investigated the effect of alternaric acid, a host-specific toxin produced by the plant fungal pathogen Alternaria solani (Pleosporaceae), on a putative plasma membrane and cytosolic kinase RiCDPK2 of potato (Solanum tuberosum) and on hypersensitive cell death of host potato cells. Alternaric acid, in the presence of $\mathrm{Ca}^{2+}$ and $\mathrm{Mg}^{2+}$, stimulated in vitro phosphorylation of His-tagged RiCDPK2, a $\mathrm{Ca}^{2+}$-dependent protein kinase found in potato plants. We concluded that $\mathrm{Ca}^{2+}$ and $\mathrm{Mg}^{2+}$ play an important role in the interaction between alternaric acid and RiCDPK2. Based on our observations, alternaric acid regulates RiCDPK2 kinase during the infection process in an interaction between host and A. solani, leading to the inhibition of hypersensitive cell death in the host. We suggest that alternaric acid is a primary determinant
\end{abstract}


by which $A$. solani stimulates CDPK activity in the host, suppressing hypersensitive cell death.

Key words: Alternaria solani; Alternaric acid; Phosphorylation; CDPK; Host-selective toxin; Hypersensitive cell death

\section{INTRODUCTION}

Host-selective toxins (HSTs) are low molecular weight secondary metabolites belonging to various classes of chemical compounds (Otani, 2000). HSTs have been reported as the primary determinants of pathogenesis in host cell recognition and disease development. Toxins cause physiological changes in host cells and alter cell membrane permeability, resulting in the rapid increase of electrolyte loss (Langsdorf et al., 1990; Otani et al., 1995; Otani, 2000) and decrease in the membrane potential (Furuichi et al., 1992). Alternaric acid (AA) was reported to play a role in determining host specificity and contributing to disease development caused by Alternaria solani (Furuichi and Nishimura 1984; Langsdorf et al., 1990). When treated with AA, slices of potato tubers infected with an incompatible race of Phytophthora infestans showed delayed hypersensitive cell death (HR), suggesting that AA is a fungal suppressor (Furuichi et al., 1992). Tabuchi and Ichihara (1992) reported the complete stereochemistry and synthesis of AA. Biological Diels-Alder reaction was found to be involved in the polyketide pathway for the production of AA (Tabuchi et al., 1994).

Suppressor molecules from compatible pathogens caused the inhibition of HR. Suppressors isolated from $P$. infestans are soluble glucans containing units bonded via $\beta-1,3$ and ß-1, 6 linkages (Doke et al., 1979; Furuichi and Suzuki, 1990). $\mathrm{Ca}^{2+}$-dependent phosphorylation of various potato proteins was reported after treatment with elicitors such as hydrogen peroxide, salicylic acid, and suppressor glucan from P. infestans (Furuichi et al., 1994). This indicated that $\mathrm{Ca}^{2+}$-dependent protein kinase(s) (CDPKs) played a role in eliciting host response to various stimuli. CDPKs are multifunctional and are present in several isoforms that regulate specific pathways to control transcription, metabolic enzyme activities, membrane transport, and cell structure (Harmon et al., 2000).

In this study, we investigated the effect of AA on the phosphorylation of purified Histagged RiCDPK2 (DDBJ accession number, AB051809), a new isoform of the CDPK gene family from potato tuber cv. Rishiri. This cultivar is highly resistant to P. infestans (Okuta et al., 1999). We further investigated the role of $\mathrm{Ca}^{2+}$ and $\mathrm{Mg}^{2+}$ in the interaction of AA and HisRiCDPK2. This study aimed to determine the role of AA as an HST and its effect on HR in potato and tomato and to compare the effect of the HST with that of an HR suppressor in the host-P. infestans interaction.

\section{MATERIAL AND METHODS}

\section{Leaf bioassay}

AA used in this study was purified from cultured fluid of $A$. solani, as reported previously (Langsdorf et al., 1989). The fungus was grown in potato glucose medium at $25^{\circ} \mathrm{C}$ for 25 days. The cultured fluid was fractionated by silica gel column chromatography, and AA was eluted 
using a mixture of chloroform and ethanol (19:1, v/v), as reported by Furuichi et al. (1992). The biological effect of AA on plant leaves was studied using fully expanded compound leaves from tomato cv. Fukuju II. Leaves were disinfected with $0.1 \%$ sodium hypochlorite and rinsed several times with distilled water. The surface of 2 leaves per plant was gently punctured uniformly over an area of $\sim 15 \mathrm{~mm}^{2}$ with a needle before AA treatment. Leaves were treated with $30 \mu \mathrm{LAA}(0.1$, $0.25,2.5$, and $25 \mu \mathrm{M}$ each on different leaves) and incubated under aseptic moist conditions at $23^{\circ} \mathrm{C}$ for $14 \mathrm{~h}$ under light. The leaves were assessed for necrosis $24 \mathrm{~h}$ after AA treatment.

\section{Preparation of a cDNA library and DNA templates for polymerase chain reaction (PCR)}

Total RNA was isolated from potato leaves and tuber disks according to the method of Nagy et al. (1988) and purified by chromatography by using oligo (dT) cellulose, as described previously (Sambrook and Russell, 2001). Double-stranded cDNA was synthesized from poly $(A)^{+}$-RNA by using a cDNA synthesis System Plus (Amersham Bioscience, Tokyo). cDNA libraries were constructed using a cDNA cloning system lambda gt11 (Amersham Bioscience, Tokyo). DNA templates were prepared from the cDNA libraries by phenol extraction (Novagen, Tokyo) and amplified by PCR by using primers that corresponded to the 2 adapters of the insert cDNAs (Mizoguchi et al., 1993).

\section{Preparation of His-RiCDPK2}

RiCDPK2 was isolated from potato tuber $\mathrm{cv}$. Rishiri having $\mathrm{R}_{1}$-resistance gene to $P$. infestans (Okuta et al., 1999). RiCDPK2 contains a kinase domain, 31 amino acid putative autoinhibitory domain, and $\mathrm{Ca}^{2+}$-binding regulatory domain at the $\mathrm{C}$-terminus. The putative autoinhibitory domain presumably functions as a pseudosubstrate inhibiting phosphorylation reactions in the absence of $\mathrm{Ca}^{2+}$ (Harper et al., 1993; Harmon et al., 1994). This domain also contains a potential autophosphorylation site (Lys-Gln-Phe-Ser) (Harmon et al., 2000). A BLAST search of the DNA Data Bank of Japan (DDBJ) database revealed that the amino acid sequence corresponding to the serine/threonine protein kinase active site and the autophosphorylation site within RiCDPK2 are 100\% identical to the respective sites in AK1 from Arabidopsis thaliana (Harper, 1993). RiCDPK2 possesses 33 serine and 21 threonine residues with a TGA stop codon at 1500 base pair $(\mathrm{bp})$ from the ATG start codon at the N-terminal priming site.

The complete RiCDPK2 cDNA (1488 bp) was cloned into the pCR-expression vector (Invitrogen, Carlsbad, USA) and used to transform Escherichia coli (BL21 pLysS) for expression according to the reported method (Sambrook and Russell, 2001). Protein expression was induced by adding $0.6 \mathrm{mM}$ isopropyl- $\beta$-D-thiogalactopyranoside (IPTG) to the Luria-Bertani (LB) culture medium supplemented with $70 \mu \mathrm{g} / \mathrm{mL}$ ampicillin containing transformed $E$. coli cells. The cells were incubated on a shaker for $24 \mathrm{~h}$ at $25^{\circ} \mathrm{C}$ and harvested at $4000 \mathrm{rpm}$ for $10 \mathrm{~min}$ at $4^{\circ} \mathrm{C}$. The protein was isolated in guanidinium lysis buffer by centrifugation at $6,500 \mathrm{rpm}$ for $15 \mathrm{~min}$ at $4^{\circ} \mathrm{C}$ by using an RPR-20 rotor (Hitachi). The supernatant was collected, and purification was achieved using a histidine affinity column according to manufacturer instructions (Invitrogen Xpress ${ }^{\mathrm{TM}}$ System; Netherlands). Purified His-RiCDPK2 was extensively dialyzed using $10 \mathrm{mM}$ Tris- $\mathrm{HCl}$ $(\mathrm{pH} 8.0,0.1 \%$ Triton $\mathrm{X}-100)$. The protein concentration was determined using the Bio-Rad protein assay kit according to the Bradford (1976) by using bovine serum albumin (BSA) as a standard. The final concentration of the His-tagged protein ranged from 80 to $100 \mu \mathrm{g} / \mathrm{mL}$. 


\section{Phosphorylation assay}

Purified His-RiCDPK2 was used for the phosphorylation assay. Effect of AA on HisRiCDPK2 phosphorylation in the presence of $\mathrm{Ca}^{2+}$ and $\mathrm{Mg}^{2+}$ was studied in vitro using the assay reported by Furuichi et al. (1994). Assays were performed in a 96-well microtiter plate, with a total volume of $155 \mu \mathrm{L}$ per well. The reaction mixture contained $8.5 \mathrm{mM}$ Tris- $\mathrm{HCl}$ (pH 7.1), $5 \mathrm{mM}$ phosphocreatine (Sigma, St. Louis), $0.4 \mathrm{U}$ creatine phosphokinase (Sigma, St. Louis), and $1.5 \mu \mathrm{g}$ His-RiCDPK2. The effect of AA on the phosphorylation of RiCDPK2 was determined by treating the respective sample with $25 \mu \mathrm{M} \mathrm{AA}$. The effect of AA on HisRiCDPK2 phosphorylation in the presence of $\mathrm{Ca}^{2+}$ and $\mathrm{Mg}^{2+}$ was determined by conducting phosphorylation experiments in the absence or presence of $100 \mu \mathrm{M} \mathrm{Ca}^{2+}$ and $0.9 \mathrm{mM} \mathrm{Mg}^{2+}$ in the reaction mixture. Assays were initiated by adding $0.9 \mathrm{mM}$ ATP, followed by incubation at $30^{\circ} \mathrm{C}$ for $10 \mathrm{~min}$. Subsequently, 1-naphthol $(0.2 \%$; Wako, Tokyo) dissolved in stock alkali solution (1.5 M NaOH, 0.7 $\mathrm{M} \mathrm{NaCO}_{3}$ ) and 2,3-butane dione (0.06\%; Wako, Tokyo) was added to each sample for color development. The absorbance was determined using a micro plate reader (BioRad 3500) at $595 \mathrm{~nm}$ at 10-min intervals for $40 \mathrm{~min}$. The temperature during the reading intervals was maintained at $30^{\circ} \mathrm{C}$.

\section{RESULTS}

\section{AA causes veinal necrosis}

A leaf puncture on the center of the leaves with a needle was used to investigate the effect of AA on plant tissues. Different concentrations of AA were used to test the effect on tomato leaves (Figure 1A). Characteristic symptoms of toxicity by AA are veinal necrosis (Figure 1A, b, c) and intercostal necrosis (Figure 1A, a) in tomato leaves and a broad chlorosis, which subsequently becomes necrotic. A biological assay showed that the severity of necrosis caused by AA in tomato leaves was concentration-dependent (Figure 1A). Veinal necrosis became visible on the leaves treated with $0.25 \mu \mathrm{M}$ AA within $24 \mathrm{~h}$ of application (Figure 1A, c). Severe veinal necrosis of the tomato leaf blade was observed when the leaves were treated with $25 \mu \mathrm{M}$ AA (Figure 1A, a). In the present study, $0.1 \mu \mathrm{M} \mathrm{AA}$ also caused yellowing of the treated site of the leaf (Figure 1A, d). In contrast, as shown in Figure 1B, A. solani caused symptoms in tomato leaves 2 days after inoculation, and the necrosis spread further during the next 5 days after infection. These symptoms (Figure 1B) are different from the veinal necrosis caused by AA treatment (Figure 1A).

AA treatment did not induce HR in tomato cells $24 \mathrm{~h}$ after treatment, as shown by microscopic observation (data not shown). The necrotic symptoms were caused by AA treatment. This necrotic response of the tomato tissue to AA clearly differs from the early and localized reaction to the infection caused by an incompatible race of $P$. infestans that causes HR in the host cells.

\section{His-RiCDPK2 requires $\mathrm{Ca}^{2+}$ and $\mathrm{Mg}^{2+}$ for activation}

His-RiCDPK2 was expressed in E. coli cells as a fusion protein with $6 \mathrm{X}$ His tags (Hong et al., 1999). The His-RiCDPK2 was recovered mainly in the insoluble protein fraction, although a small amount of the protein was also recovered in the soluble fraction. His-tagged 
RiCDPK2 was $\sim 90 \%$ pure as revealed by sodium dodecyl sulfate-polyacrylamide gel electrophoresis (SDS-PAGE). His-RiCDPK2 was phosphorylated only in the presence of $\mathrm{Ca}^{2+}$ and $\mathrm{Mg}^{2+}$ or $\mathrm{Ca}^{2+}$ alone (Figure 2B).

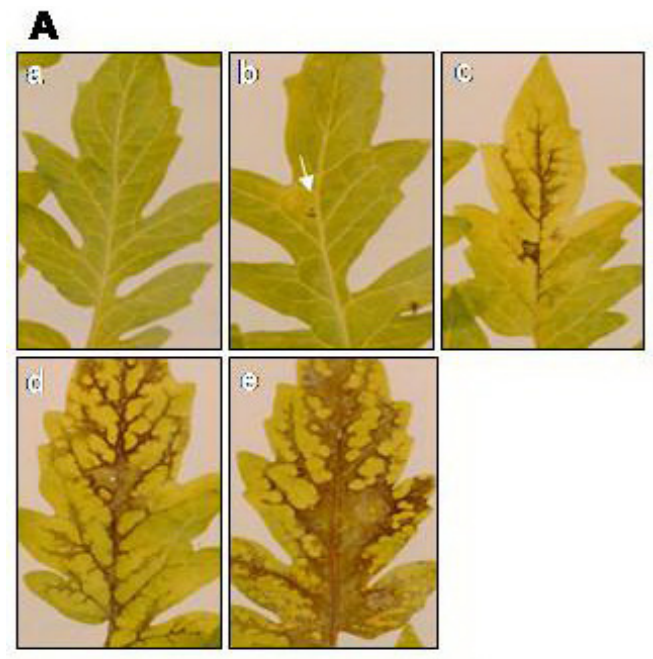

\section{B}
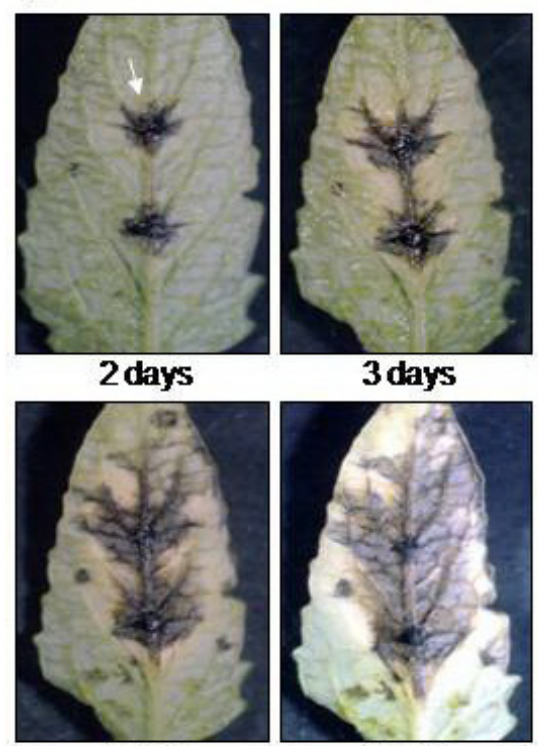

4 days

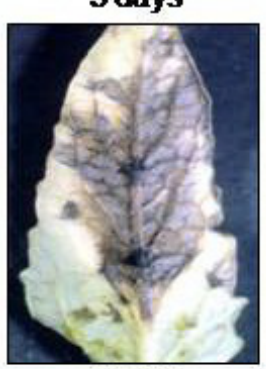

5 days

Figure 1. Bioassay of tomato leaf treated with different concentrations of alternaric acid (AA) produced by Alternaria solani. A. The leaf surface was gently punctured with a needle and treated with micromolar concentrations of AA. The observations were made $24 \mathrm{~h}$ after AA treatment. Treated leaves were incubated under aseptic moist conditions at $23^{\circ} \mathrm{C}$ for $14 \mathrm{~h}$ light period. AA concentrations: a, $25 \mu \mathrm{M} ; \mathrm{b}, 2.5 \mu \mathrm{M} ; \mathrm{c}, 0.25 \mu \mathrm{M} ; \mathrm{d}, 0.1 \mu \mathrm{M}$; and e, control (water). B. Alternaria solani infection on tomato leaves. Observations were made after 2, 3, 4, and 5 days of the inoculation. A. solani produced AA in the infected plant tissue and neighboring cells causing necrosis through the veins. 

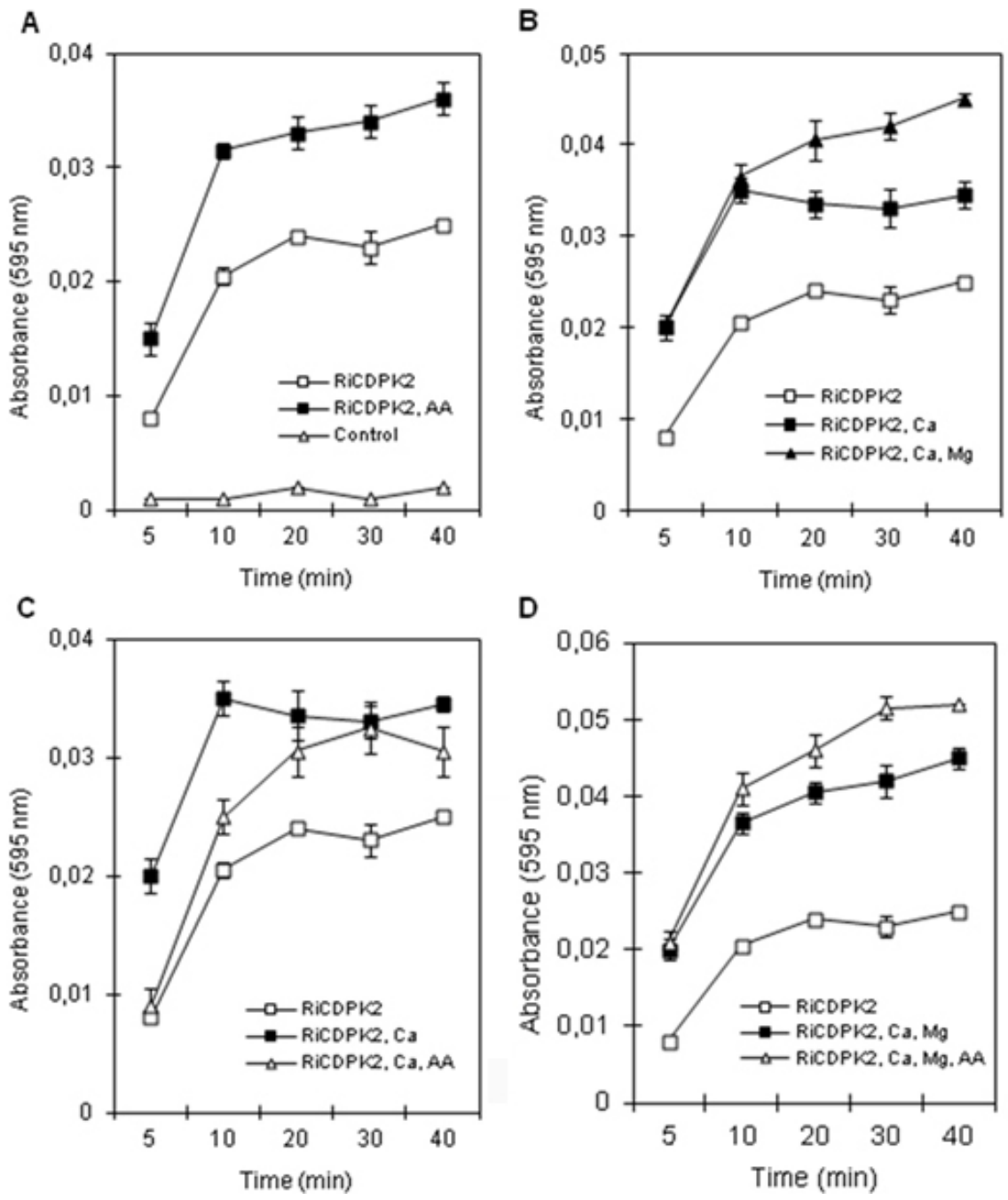

Figure 2. Effect of alternaric acid (AA) on the phosphorylation of His-RiCDPK2 in the presence of $\mathrm{Ca}^{2+}$ and/or $\mathrm{Mg}^{2+} \mathrm{A}$, Effect of AA; B, effect of $\mathrm{Ca}^{2+}$ or $\mathrm{Mg}^{2+}$; C, effect of AA with $\mathrm{Ca}^{2+}$; D, effect of AA with $\mathrm{Ca}^{2+}$ and $\mathrm{Mg}^{2+}$. The final concentrations were: RiCDPK2 $(1.5 \mu \mathrm{g})$, AA $(25 \mu \mathrm{M})$. The control treatment (absence of His-RiCDPK2) was identical for all the experiments in panels A-D. Data represent the mean of two independent experiments \pm SD.

\section{Effect of AA on His-RiCDPK2 in the presence of $\mathrm{Ca}^{2+}$ and $\mathrm{Mg}^{2+}$}

His-RiCDPK2 phosphorylation was immediately stimulated to $\sim 4 \%$ in the presence of AA compared to that without AA (Figure $2 \mathrm{~A} ; \mathrm{t}=5$ ). The stimulation of RiCDPK2 phosphorylation occurred until $40 \mathrm{~min}$ in the presence of AA than that without AA addition. The effect of AA on His-RiCDPK2 phosphorylation was measured in the absence or presence of either $\mathrm{Ca}^{2+}$ alone or $\mathrm{Ca}^{2+}$ and $\mathrm{Mg}^{2+}$ together. AA showed different effects on RiCDPK2 phos- 
phorylation in the presence of $\mathrm{Ca}^{2+}$ alone (Figure 2C) and $\mathrm{Ca}^{2+}$ and $\mathrm{Mg}^{2+}$ together (Figure 2D). AA initially inhibited phosphorylation by $\sim 53 \%$ with $\mathrm{Ca}^{2+}$ alone (Figure $2 \mathrm{C} ; \mathrm{t}=0$ ). The inhibition of RiCDPK2 phosphorylation by AA in the presence of $\mathrm{Ca}^{2+}$ decreased over time, and the activity was almost the same with and without AA after 30 min and was slightly stimulated at 40 min (Figure 2C). When $\mathrm{Mg}^{2+}$ was added to RiCDPK2 containing $\mathrm{Ca}^{2+}, 46 \%$ stimulation of RiCDPK2 phosphorylation was observed after the initiation of the reaction (Figure $2 \mathrm{~B} ; \mathrm{t}=$ 5). In the presence of both $\mathrm{Ca}^{2+}$ and $\mathrm{Mg}^{2+}$, AA stimulated RiCDPK 2 phosphorylation to $\sim 12 \%$ (Figure 2D). This stimulation of RiCDPK2 phosphorylation in AA-treated samples in the presence of $\mathrm{Ca}^{2+}$ and $\mathrm{Mg}^{2+}$ was $22 \%$ higher (Figure 2D) than that observed in the absence of these cations (Figure 2A). This indicated that the presence of both $\mathrm{Ca}^{2+}$ and $\mathrm{Mg}^{2+}$ in the assay played a role in the stimulation of RiCDPK2 phosphorylation in AA-treated samples. In a similar experiment, an HR suppressor from P. infestans also stimulated the phosphorylation of RiCDPK2 in the presence of $\mathrm{Ca}^{2+}$ and $\mathrm{Mg}^{2+}$ just after addition under the same conditions (data not shown).

The present results indicate that the difference between phosphorylation stimulation of His-RiCDPK2 in AA-treated samples in the presence and absence of $\mathrm{Ca}^{2+}$ and $\mathrm{Mg}^{2+}$ together is stronger (Figure 2D) than that observed in the presence and absence of $\mathrm{Ca}^{2+}$ alone (Figure 2C). AA inhibited the phosphorylation of RiCDPK2 in the presence of $\mathrm{Ca}^{2+}$ (Figure 2C) and stimulated it in the presence of $\mathrm{Ca}^{2+}$ and $\mathrm{Mg}^{2+}$ together (Figure 2D). These results showed that $\mathrm{Ca}^{2+}$ and $\mathrm{Mg}^{2+}$ both were required for AA and RiCDPK2 interaction.

\section{DISCUSSION}

The key role of HSTs in pathogenesis is assumed to be similar to that of a suppressor of host resistance mechanisms (Furuichi and Nishimura 1984; Furuichi et al., 1984; Langsdorf et al., 1989; Oku et al., 1993). AA mimics HSTs during disease development, showing an early effect on the plasma membrane of host cells (Nishimura and Kohmoto 1983; Langsdorf et al., 1991; Otani et al., 1995). As reported previously, AA significantly delayed the occurrence of HR in potato cells infected with an incompatible strain of $P$. infestans, but the treatment had no effect on the hyphal growth of P. infestans in the infected cells (Furuich et al., 1992). The present study indicated that AA directly affected the activity of His-RiCDPK2. These findings suggest that HST causes a significant delay of HR, and HR is initiated in the host cells when AA stimulates RiCDPK2. In potato, early inhibition of HR seems to be important for successful infection and establishment of disease (Furuichi et al., 1992). In the case of tomato leaves infected with $A$. solani (Figure 1B), necrosis was not restricted to veinal region (Figure 1A) but progressed to the rest of the leaf. Some other toxins such as solanapyrone A might also be produced by $A$. solani at a later stage during the infection contributing to necrosis (Figure 1B; 5 days). Production of AA per spore in the germination fluid is very low, and low concentration (less than $0.1 \mu \mathrm{M}$ ) of AA does not cause necrosis in the host leaf (Figure 1A, d; Figure 1B; before 2 days). In contrast, low concentration of AA $(0.25 \mu \mathrm{M})$ can delay HR (Furuichi et al., 1992). In the present leaf bioassay, higher the concentration of AA, greater was the damage (Figure 1A, a). The results show that $A$. solani infection produced less than $0.1 \mu \mathrm{M}$ AA and caused negligible damage at an early stage (Figure 1B; before 2 days); and the production of AA increased with time causing more damage to the leaf surface at a later stage (Figure 1B; 5 days). This finding is different from that for HR, which is localized and occurs early.

$\mathrm{Ca}^{2+}$-dependent kinase activity was stimulated by the elicitor and suppressor glucan 
from P. infestans in the potato membrane fraction (Furuchi et al., 1994). Activation of a membrane-bound CDPK of $68 \mathrm{kDa}$ has been reported in $C f-9$ tobacco cells treated with Avr9 of Cladosporium fulvum (Romeis et al., 2000). Biochemical purification and immunochemical studies of potato (Furuichi et al., 1998) and rice (Martin and Busconi, 2000) have suggested the association of CDPK with the plasma membrane. Since RiCDPK2 stimulation by AA was the primary mode of action of the toxin, RiCDPK2 might be a key kinase that regulates the inhibition of HR in the host cells. Other reports suggest that AA acts as an HST during disease development (Furuichi et al., 1984; Langsdorf et al., 1990). Several other HSTs such as ACT-, AF- and AK-toxins (produced by tangerine, strawberry and Japanese pear pathotypes of $A$. alternata, respectively) show an early effect on the plasma membrane of host cells (Langsdorf et al., 1991; Otani et al., 1995), causing electrolyte loss from the host tissue (Otani et al., 1991). Electrophysiological analyses of the host cell membranes treated with HSTs have been reported. PC-toxin from Periconia circinata inhibited the activity of the proton pump in the suceptible tissue (Gardner et al., 1972). Our results suggest that $\mathrm{Ca}^{2+}$ pumps in the potato plasma membrane might regulate RiCDPK2. Some of these plasma membrane pumps have been reported previously (Hong et al., 1999).

HSTs cause ion efflux in infected host cells, leading to the accumulation of $\mathrm{Ca}^{2+}$ and $\mathrm{Mg}^{2+}$ at the site of infection in the host. Since AA stimulates RiCDPK2 autophosphorylation in the presence of $\mathrm{Ca}^{2+}$ and $\mathrm{Mg}^{2+}$ (Figure 2D) in vitro, AA might stimulate RiCDPK2 in situ during A. solani infection in potato cells. AA might target a specific plant protein kinase, as shown in the present in vitro assay (Furuichi et al., 1994), leading to the inhibition of HR.

Our results show that AA might regulate RiCDPK2 kinase during the infection process by facilitating a compatible interaction between the host and $A$. solani, leading to the inhibition of HR.

\section{ACKNOWLEDGMENTS}

Research supported by Ministry of Education, Science and Culture, Japan. The authors gratefully acknowledge the facilitation of this work by Dr. Furuichi Naotaka, Faculty of Agriculture Niigata University, Japan.

\section{REFERENCES}

Bradford MM (1976). A rapid and sensitive method for the quantitation of microgram quantities of protein utilizing the principle of protein-dye binding. Anal. Biochem. 72: 248-254.

Doke N, Garas NA and Kuć J (1979). Partial characterization and aspects of the mode of action of a hypersensitivityinhibiting factor (HIF) isolated from Phytophthora infestans. Physiol. Plant Pathol. 15: 127-140.

Furuichi N and Nishimura S (1984). Isolation of alternaric acid from the germination fluids of Alternaria solani. Ann. Phytopathol. Soc. Jpn. 50: 128.

Furuichi N and Suzuki J (1990). Purification and properties of suppressor glucan isolated from Phytophthora infestans. Ann. Phytopathol. Soc. Jpn. 56: 457-467.

Furuichi N, Nishimura S, Kimura Y, Hamzaki H, et al. (1984). Production of alternaric acid from Alternaria solani and its pathological role. Ann. Phytopathol. Soc. Jpn. 50: 412-413.

Furuichi N, Nishimura S and Langsdorf G (1992). Effect of alternaric acid, a toxin of Alternaria solani, on the hypersensitive response of potato to Phytophthora infestans. Ann. Phytopathol. Soc. Jpn. 58: 1-7.

Furuichi N, Anderson AJ, Suzuki Y and Takemoto JY (1994). Elicitor and Suppressor of Phytophthora infestans Stimulate Phosphorylation of Plasma Membrane Proteins from Potato and Bean Tissues. In: Host Specific Toxin: Biosynthesis, Receptor and Molecular Biology (Kohmoto K and Yoder OC, eds.). Tottori University Press, Tottori, 273-274. 
Furuichi N, Suzuki Y, Matrsubara M, Aoyagi M, et al (1998). Identification of Receptor Site of the Suppressor Isolated from Phytophthora infestans in Potato Plasma Membrane by Using Surface Plasmonl Biosensor. In: Molecular Genetics of HostSpecific Toxins in Plant Disease (Kohmoto K and Yoder OC, eds.). Kluwer Academic Publisher, Netherlands, 367-368.

Gardner JM, Mansour IS and Scheffer RP (1972). Effects of the host-specific toxin of Periconia circinata on some properties of sorghum plasma membranes. Physiol. Plant Pathol. 2: 197-206.

Harmon AC, Yoo BC and McCaffery C (1994). Pseudosubstrate inhibition of CDPK, a protein kinase with a calmodulinlike domain. Biochemistry 33: 7278-7287.

Harmon AC, Gribskov M and Harper JF (2000). CDPKs - a kinase for every $\mathrm{Ca}^{2+}$ signal? Trends Plant Sci. 5: 154-159.

Harper JF, Binder BM and Sussman MR (1993). Calcium and lipid regulation of an Arabidopsis protein kinase expressed in Escherichia coli. Biochemistry 32: 3282-3290.

Hong B, Ichida A, Wang Y, Gens JS, et al. (1999). Identification of a calmodulin-regulated $\mathrm{Ca}^{2+}$-ATPase in the endoplasmic reticulum. Plant Physiol. 119: 1165-1176.

Langsdorf G, Furuichi N and Nishimura S (1989). Evaluation of Alternaric Acid in Pathogenesis of Alternaria solani. In: Host-Specific Toxins: Recognition and Specificity Factors in Plant Disease (Kohmoto K and Durbin RD, eds.). Tottori University Press, Tottori, 45-58.

Langsdorf G, Furuichi N, Doke N and Nishimura S (1990). Investigations on Alternaria solani infections: Detection of alternaric acid and a susceptibility-inducing factor in the spore-germination fluid of A. solani. J. Phytopathol. 128: 271-282.

Langsdorf G, Park P and Nishimura S (1991). Investigations on Alternaria solani infections: Effect of alternaric acid on the ultrastructure of tomato cells. Ann. Phytopathol. Soc. Jpn. 57: 32-40.

Martin ML and Busconi L (2000). Membrane localization of a rice calcium-dependent protein kinase (CDPK) is mediated by myristoylation and palmitoylation. Plant J. 24: 429-435.

Mizoguchi T, Yamaguchi-Shinozaki K, Hayashida N, Kamada H, et al. (1993). Cloning and characterization of two cDNAs encoding casein kinase II catalytic subunits in Arabidopsis thaliana. Plant Mol. Biol. 21: 279-289.

Nagy F, Kay SA and Chua NH (1988). Analysis of Gene Expression in Transgenic Plants. In: Plant Molecular Biology Manual B4 (Gelivin SV, Schilperoort RA and Verma DPS, eds.). Kluwer Academic Publishers, Dordrecht, 1-29.

Nishimura S and Kohmoto K (1983). Roles of Toxins in Pathogenesis. In: Toxins and Plant Pathogenesis (Daly JM and Deverall BJ, eds.). Academic Press, New York, 135-157.

Oku H, Shiraishi T, Kim HM, Kato T, et al (1993). Host-Selective Suppressor for Defense Response from Mycosphaerella pinodes. In: Host-Specific Toxin: Biosynthesis, Receptor and Molecular Biology (Kohmoto K and Yoder OC, eds.). Tottori University Press, Tottori, 49-59.

Okuta T, Furuichi N and Kusakari T (1999). Cloning of potato CDPK genes coding the receptor protein for the suppressor of Phytophthora infestans. Ann. Phytopathol. Soc. Jpn. 65: 327.

Otani H (2000). Host recognition by plant pathogens and role of host-specific toxins. J. Gen. Plant Pathol. 66: 278-280.

Otani H, Kohmoto K, Kodama M and Nishimura S (1991). Role of Host-Specific Toxins in the Pathogenesis of Alternaria alternata. In: Molecular Strategies of Pathogens and Host Plants (Patil SS, ed.). Springer-Verlag, New York, 147-149.

Otani H, Kohmoto K and Kodama M (1995). Alternaria toxins and their effects on host plants. Can. J. Bot. 73: 453-458.

Romeis T, Piedras P and Jones JD (2000). Resistance gene-dependent activation of a calcium-dependent protein kinase in the plant defense response. Plant Cell 12: 803-816.

Sambrook J and Russell DW (2001). Molecular Cloning: A Laboratory Manual. Vol. 1. Cold Spring Harbor Laboratory Press, New York.

Tabuchi H and Ichihara A (1992). Stereochemistry of alternaric acid; synthesis of the C (9)-C (14) fragment. Tetrahedron Lett. 33: 4933-4936.

Tabuchi H, Oikawa H and Ichihara A (1994). Biosynthetic study of alternaric acid: isolation of plausible biosynthetic intermediates and origins of the hydrogen and oxygen atoms. J. Chem. Soc. Perkin Trans. 1: 2283-2839. 